\title{
Ulcerative colitis and Escherichia coli with adhesive properties
}

\author{
D A BURKE, A T R AXON \\ From the Gastroenterology Unit, General Infirmary, Leeds
}

SUMMARY A quantitative assessment of the mannose resistant, adhesive property of Escherichia coli from patients with ulcerative colitis and from controls was made using a buccal epithelial cell adhesion assay, which also permitted assessment of adhesion to cells from other host sources. $E$ coli from patients with ulcerative colitis adhered to buccal epithelial cells to a greater extent than those obtained from controls ( $p<0.0001$ ), but did not show an increased affinity for the buccal epithelial cell of their host, compared with those obtained from other sources. The mannose resistant adhesive property of $E$ coli raises the possibility that it has a role in the pathogenesis of ulcerative colitis.

The aetiology of ulcerative colitis is unknown, but research has often focused on bacteria. The clinical similarity between infectious colitides and ulcerative colitis at presentation, the limitation of the disease to the colon with its abundant microflora, and the difficulties in inducing experimental colitis in germ free animals ${ }^{1}$ all suggest that bacteria may have a role in the pathogenesis of ulcerative colitis.

There have been conflicting reports about the ratio of Escherichia coli to total viable bacteria in the stools of colitic patients compared with those of controls, ${ }^{2-5}$ but $E$ coli from patients with ulcerative colitis have a greater ability to degrade mucins, ${ }^{2}$ and to produce necrotoxins and haemolysins ${ }^{6}$ than those from controls. Humoral antibodies to certain $E$ coli serotypes cross react with the colonic epithelium. ${ }^{7} E$ coli are now recognised as pathogens in a variety of intestinal disorders, both in animals and in $\operatorname{man},{ }^{8}$ and there is growing evidence that mucosal adhesion may have to occur before their pathogenicity can be fully expressed. ${ }^{9}$

Studies using HeLa cells have shown that up to $35 \%$ of patients harbour $E$ coli with adhesive properties, ${ }^{10}$ compared with $5 \%$ of controls. The HeLa cell assay used was not quantitative, and did not differentiate between the mannose sensitive adhesion mediated by type 1 pili, and the mannose resistant adhesins that are expressed by pathogenic $E$ coli. HeLa cell methods have several disadvantages in the investigation of intestinal adherence: they are unrelated to the gut, the cells are of neoplastic origin,

Accepted for publication 9 February 1987 and enzymatic stripping methods have to be used in the manipulation of the cell line, which may result in the expression of non-physiological receptors for bacteria. Furthermore, the method does not permit the assessment of host factors that might influence bacterial adhesion. We therefore used a buccal epithelial cell adhesion assay similar to that previously described by Gibbons and van Houte ${ }^{11}$ and Ofek et al. ${ }^{12}$ This technique enables a quantitative assessment of bacterial adhesion to cells from different host sources to be made. ${ }^{13}$

This study aimed to compare the mannose resistant adhesive property of $E$ coli isolated from colitic patients with those from controls using cells more closely associated with the gut than HeLa cells, and by using a quantitative method to assess the contribution that host factors may have in the adhesion of bacteria to cells.

\section{Patients and methods}

$E$ coli were isolated from the stools of 18 patients presenting with acute relapses of histologically confirmed ulcerative colitis. $E$ coli were also obtained from the stools of 15 patients and members of staff with no evidence of inflammatory bowel disease. One colony from each sample was chosen at random for $\bullet$ use in adhesion studies, and stored in liquid nitrogen. Ten colonies from each sample were stored on Dorset egg slopes for future analysis. Strain E851/71, a Hep2 cell adhesive strain, and strain SC13, a non-adhesive strain, (supplied by Dr RC George, Public Health Laboratory, Colindale, England) were included as markers. 
For the adhesion studies, isolates were coded and assayed without knowledge of their source. They were grown for 18 hours at $37^{\circ} \mathrm{C}$ on agar slopes (Oxoid blood base agar No 2). Bacteria were washed from the slope using phosphate buffered saline (PBS), $\mathrm{pH} 7 \cdot 2$, and the concentration adjusted to $\simeq 1 \times 10^{8}$ bacteria/ml.

Buccal epithelial cells were obtained by gently scraping the buccal mucosa with a sterile spatula. They were suspended in PBS, washed four times and, to inhibit type 1 pilus mediated adhesion, resuspended in PBS containing D-mannose $(28 \mathrm{mmol} / \mathrm{l})$ at a concentration $\simeq 1 \times 10^{5} \mathrm{cells} / \mathrm{ml}$; $0.5 \mathrm{ml}$ of each of the bacterial and the buccal epithelial cell suspensions were mixed for $\mathbf{3 0}$ minutes in a sterile bijou bottle at room temperature on a rotary roller.

Buccal epithelial cells were harvested by washing four times over a $5 \mu \mathrm{m}$ millipore filter (Nuclepore) with PBS. An impression smear was made on to a clear glass slide, air dried, fixed in methanol for two minutes, and stained by Gram's method. For each buccal epithelial cell source, a control without added bacteria was included.

The degree of mannose resistant adhesion was assessed, as described by Ofek et $\mathbf{l}^{\mathbf{1 2}}$ by inspecting 100 non-overlapping buccal epithelial cells in at least 10 high power fields, and recording the number of cells with more than 50 adherent Gram negative rods. The control cell count was subtracted from this to derive an adhesion index (\% buccal epithelial cell). Any buccal epithelial cell source, in which the control cell count was greater than $10 \%$, implying oral contamination, was excluded from analysis.

The Mann-Whitney $U$ test was used to assess the significance of differences between independent groups, and Friedman's two way analysis of variance by ranks was used to assess differences between samples.

\section{Results}

In our laboratory using this method the mean (SEM) difference between duplicate buccal epithelial cell assays was $8.13 \%(0.93)$. The adhesion indices for colitic $E$ coli isolates (median adhesion index $=43.5$ (range 18-68)) were significantly greater $(\mathrm{p}<0.0001)$ than those for control isolates (median $=2 \cdot 0$, range 0-15) (fig 1). Strains E851/71 and SC13 had adhesion indices of 47 and 6 , respectively.

The pattern of adhesion was predominantly diffuse. Only occasionally were clusters of bacteria noted, and always in association with the diffuse pattern. There was no significant difference in the number of clusters noted per 100 cells between the colitic and control bacteria. Using a single adhesive colitic strain there was no significant difference in the degree of adhesion to buccal epithelial cells between colitic patients and controls (fig 2). Similarly, using a non-adhesive, noncolitic $E$ coli there was no significant difference in adhesion to buccal epithelial cells obtained from patients or controls (fig 2).

$E$ coli from five patients were tested with their own buccal epithelial cells as well as with those from other sources (fig 3). Adhesion of the host's isolate to the host's buccal epithelial cells was no greater than that to buccal epithelial cells from other sources. Buccal epithelial cells from two colitic patients and three controls were also used in adhesion assays with five different $E$ coli isolates (three patients and two controls); the assays were performed on the same occasion to eliminate any variation related to time or conditions. Each source of buccal epithelial cell ranked the $E$ coli isolates similarly, based on their adhesion indices. The difference was highly significant $(\mathrm{p}<0.01)$.

\section{Discussion}

The ability of $E$ coli $^{14}$ and other bacteria to adhere to eukaryotic cells enables them to colonise cells by overcoming the protective mechanisms of the host, and to express fully their other pathogenic properties. Intestinal adherence has been shown to be an important factor in the pathogenesis of infection with

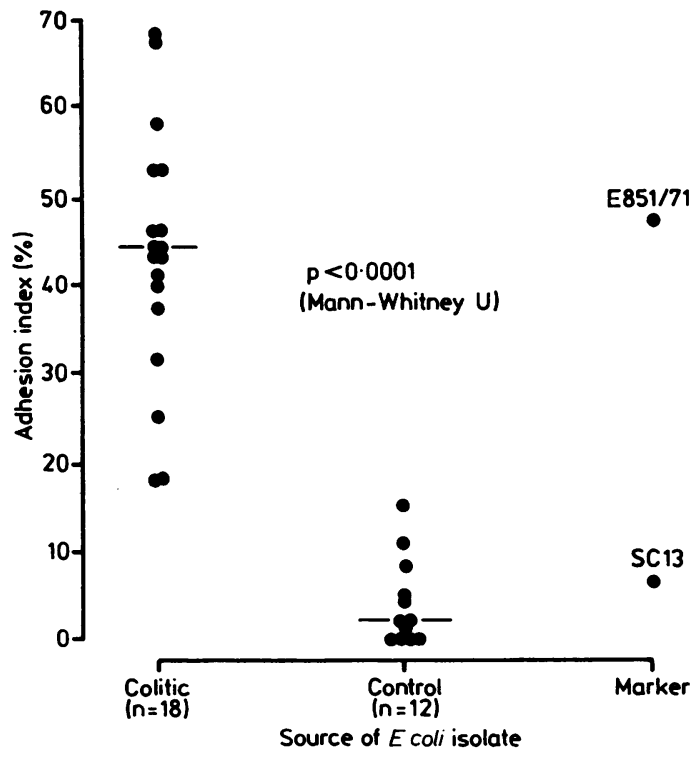

Fig 1 Comparison of adhesion of $E$ coli isolates from colitic patients and controls with single source of buccal epithelial cells. 


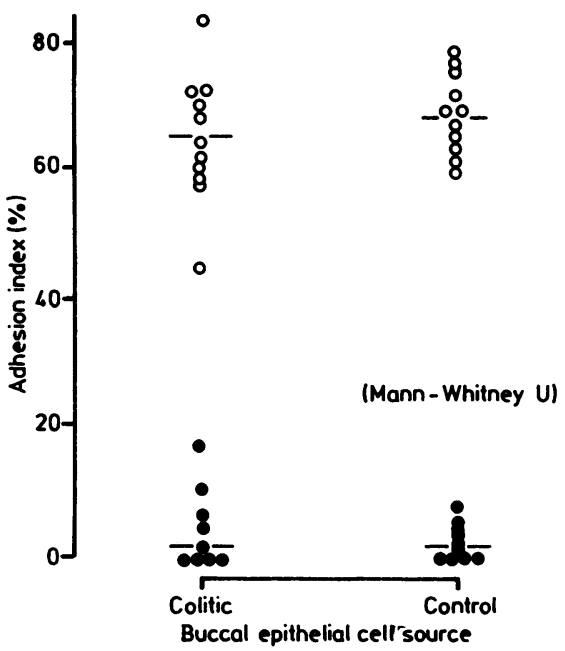

Fig 2 Adhesion of "adhesive" E coli strain (open circles $\bigcirc$ ) to buccal epithelial cells and colitic patients and controls, and of "non-adhesive" E coli (closed circles 0 ).

both enterotoxigenic ${ }^{15}$ and enteropathogenic $E$ coli. ${ }^{16}$

In acute cholera vibrios are harboured in the mouth for up to three days, ${ }^{17}$ and enterotoxigenic $E$ coli have been cultured from the oropharynx of children with chronic diarrhoea. ${ }^{18}$ Furthermore, an adhesive $E$ coli has been shown to have a similar degree of adhesion for both buccal epithelial cells and fetal enterocytes. ${ }^{19}$ These data suggest that buccal epithelial cells are suitable for the in vitro assessment of intestinal adhesion, as they may express receptors similar to those in the intestine.

This study shows that $E$ coli isolated from patients with ulcerative colitis adhere in a mannose resistant way to human epithelial cells significantly better than isolates from controls, and the buccal epithelial cell assay clearly differentiates the isolates according to their adhesive properties. The fact that all $E$ coli isolates from patients with colitis tested in our study were more adhesive than any control isolate, suggests that the incidence of $35 \%$ reported by Dickinson et al, ${ }^{10}$ for patients in relapse who carry potentially pathogenic $E$ coli, is an underestimate, and implies that the HeLa cell assay used-if measuring the same factor-is less sensitive than the buccal epithelial cell assay in differentiating colitic from control isolates.

Using a similar assay, Candy et al $^{13}$ showed that $E$ coli from children with protracted diarrhoea adhered more avidly to their own buccal epithelial cells than to those of healthy adults. Similarly, a recognised nonadhesive $E$ coli adhered more strongly to the buccal epithelial cells of patients with protracted diarrhoea than to those of controls, showing a predisposition to colonisation in this group. The $E$ coli isolates from colitic patients did not have a greater affinity for the buccal epithelial cells of their host, or those of other colitic patients, compared with the buccal epithelial cells of controls, suggesting that their presence in the stool of colitic patients was not due to host susceptibility. This result, however, cannot necessarily be extrapolated to the colon, as it is not known whether colitic colonocytes are more receptive to these strains.

Previous work from this laboratory, ${ }^{10}$ together with other studies, ${ }^{20-22}$ and plasmid profiles of faecal $E$ coli in health and disease (unpublished observations) have shown that in some instances more than one serotype may be present, but in most cases one strain predominates and may form up to $85 \%$ of the population of $E$ coli. ${ }^{20}$ In view of this and the fact that we were examining a property not necessarily related to the serotype (many recognised adhesins are mediated by plasmids) one colony was chosen at random for the adhesion studies.

The presence of adhesive $E$ coli in patients with ulcerative colitis may be an incidental finding, and they may not have a direct role in the pathogenic process; indeed, the inflammatory process within the colon may result in the exposure of receptors that would otherwise be masked, resulting in the selection of strains with an appropriate adhesin. Neuraminidase has been shown experimentally to enhance adhesion of Actinomyses viscosis and Actinomyces naeslundii to red blood cells by removing terminal sialic acid residues, thus unmasking receptors, ${ }^{23}$ and Parsons $e a^{24}$ have shown enhanced adhesion of $E$ coli to rabbit bladder after exposure to neuraminidase. Host or other bacterial enzymes may operate to bring about the same "unmasking" effect for $E$ coli in ulcerative colitis.

Using HeLa cells, Dickinson $e^{2} a^{25}$ showed that a greater proportion of adhesive strains were present in

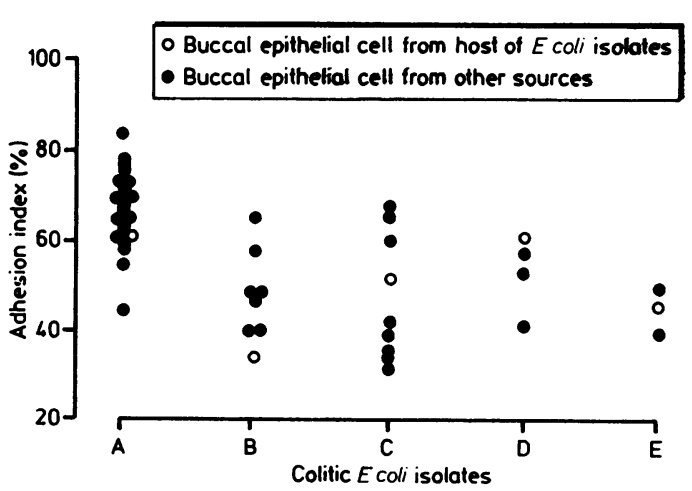

Fig 3 Adhesion of colitic E coli isolates to host buccal epithelial cells and other sources of buccal epithelial cells. 
the first attack of colitis than during a relapse. If damage to the intestinal mucosa was the prime reason for their presence it might be expected that patients with chronic disease would have an increased incidence of adhesive strains.

There are anecdotal reports of ulcerative colitis occurring after infection with recognised intestinal pathogens. ${ }^{26-28}$ Hurst used the term "post dysenteric colitis", even though an organism could not be isolated. ${ }^{29}$ Plasmids coding for adhesins have been transferred between $E$ coli, ${ }^{30-32}$ and virulence factors for Shigellae have been transferred to $E$ coli. ${ }^{33}$ This raises the possibility that adhesive $E$ coli in patients with colitis may have acquired the property from another source, and could explain the chronicity of ulcerative colitis in the absence of a persistent recognised pathogen.

In vitro studies using a genetically cloned $E$ coli 536, which has a mannose resistant adhesin and the ability to produce haemolysin, have shown that the presence of the adhesin increases the release of inflammatory mediators. ${ }^{34}$ Pigs and calves can be protected from diarrhoea caused by enterotoxigenic $E$ coli by passively induced immunity, monoclonal antibodies, and antisera directed against the bacterial adhesin. Hydrophobic gels that can bind to the colonisation factor antigen adhesin prevent enterotoxigenic $E$ coli diarrhoea in infant rabbits. ${ }^{35-38}$

The finding of a mannose resistant adhesin in isolates of $E$ coli from patients with colitis, raises the possibility of their having a role in the pathogenesis of ulcerative colitis, and offers hope for new treatment strategies. Further studies are required to identify the nature and the exact role of adhesive $E$ coli in ulcerative colitis.

\section{References}

1 Onderdonk AB, Bartlett JG. Bacteriological studies of experimental ulcerative colitis. Am J Clin Nutr 1979;32:258-65.

2 Van der Wiel-Korstanje JAA, Winkler KC. The faecal fiora in ulcerative colitis. J Med Microbiol 1975;8:491-501.

3 Gorbach SL, Nahas L, Plaut AG, Weinstein L, Patterson JF, Levitan R. Studies of intestinal microflora V. Fecal microbial ecology in ulcerative colitis and regional enteritis: relationship to severity of disease and chemotherapy. Gastroenterology 1968;54:575-87.

4 Keighley MRB, Arabi Y, Dimock F, Burdon DW, Allan RN, Alexander-Williams J. Influence of inflammatory bowel disease on intestinal microflora. Gut 1978;19:1099-104.

5 Cooke EM. A quantitative comparison of the faecal flora of patients with ulcerative colitis and that of normal persons. Journal of Pathology and Bacteriology 1967;94:439-44.

6 Cooke EM, Ewins SP, Hywel-Jones J, Lennard-Jones JE. Properties of strains of Escherichia coli carried in different phases of ulcerative colitis. Gut 1974;15:143-6.

7 Perlmann P, Hammarstrom S, Lagercrantz R, Campbell D. Autoantibodies to colon in rats and human ulcerative colitis: cross reactivity with Escherichia coli 0:14 antigen. Proc Soc Exp Biol Med 1967;125:975-80.
8 Gross RJ, Escherichia coli diarrhoea. J Infect 1983;7:177-92.

9 Candy DCA. The role of mucosal adhesion in the pathogenesis of Escherichia coli induced diarrhoea. $J$ Trop Paediatr 1986;26:75-9.

10 Dickinson RJ, Varian SA, Axon ATR, Cooke EM. Increased incidence of faecal coliforms with in vitro adhesive and invasive properties in patients with ulcerative colitis. Gut 1980;21:787-92.

11 Gibbons RJ, Van Houte J. Selective bacterial adherence to oral epithelial surfaces and its role as an ecological determinant. Infect Immun 1971;3:567-73.

12 Ofek I, Mirelman D, Sharon N. Adherence of Escherichia coli to human mucosal cells mediated by mannose receptors. Nature 1977;265:623-5.

13 Candy DCA, Leung TSM, Marshall WC, Harries JT. Increased adhesion of Escherichia coli to mucosal cells from infants with protracted diarrhoea: a possible factor in the pathogenesis of bacterial overgrowth and diarrhoea. Gut 1983;24:538-41.

14 Ofek I, Beachey EH. General concepts and principles of bacterial adherence in animals and man. Receptors and recognition, B(6). In: Beachey EH, ed. Bacterial adherence. London: Chapman \& Hall, 1980:1-29.

15 Satterwhite TK, Evans DG, Dupont HL, Evans Jr DJ. Role of Escherichia coli colonisation factor antigen in acute diarrhoea. Lancet 1978;ii:181-4.

16 Levine MM, Nataro JD, Karch H, et al. The diarrhoeal response of humans to some classic serotypes of enteropathogenic Escherichia coli is dependent on a plasmid encoding an enteroadhesive factor. $J$ Infect Dis 1985;152:550-9.

17 Gorbach SL, Banwell JG, Jacobs B, et al. Intestinal microflora in Asiatic cholera. II. The small bowel. J Infect Dis 1970;121:38-45.

18 Challacombe DN, Richardson JM, Rowe B, Anderson CM. Bacterial microflora of the upper gastrointestinal tract in infants with protracted diarrhoea. Arch Dis Child 1974;49:270-7.

19 Candy DCA, Leung TSM, Phillips AD, Harries JT, Marshall WC. Models for studying the adhesion of enterobacteria to the mucosa of the human intestinal tract. In: Elliott K, O'Connor $\mathrm{M}$, Whelan J, eds. Adhesion and microorganism pathogenicity Ciba Foundation Symposium 80. Tunbridge Wells: Pitman Medical, 1981:72-93.

20 Wallick H, Stuart CA. Antigenic relationships of Escherichia coli isolated from one individual. $J$ Bacteriol 1943;45:121-6.

21 Bettelheim KA, Faiers M, Shooter RA. Serotypes of Escherichia coli in normal stools. Lancet 1972;ii:1224-6.

22 Vosti KL, Monto AS, Rantz LA. The importance of sample size in studies based upon the serological classification of $\mathrm{E}$ coli. Proc Soc Exp Biol Med 1962;111:210-4.

23 Ellen RP, Fillery ED, Chan KH, Grove DA. Sialidase-enhanced lectin-like mechanism for Actinomyces viscosus, and Actinomyces Naeslundii haemagglutination. Infect Immun 1980;27:335-43.

24 Parsons CL, Shrom SH, Hanno PM, Mulholland SG. Bladder surface mucin. Examination of possible mechanisms for its antibacterial effect. Investigative Urology 1978;16:196-200.

25 Dickinson RJ, Pinder IF, Dixon MF, Cooke EM, Axon ATR. High prevalence of potentially pathogenic $E$ coli in first attack of idiopathic colitis. Gut 1983;24:A997.

26 Felson J, Gorenberg H. Chronic dysentery, distal ileitis and ulcerative colitis. A follow up of the Jersey City epidemic of bacillary dysentery. Am J Med Sci 1936;192:553-6.

27 Powell SJ, Wilmot AJ. Ulcerative post-dysenteric colitis. Gut 1966;7:438-43.

28 Stewart GT. Post-dysenteric colitis. Br Med J 1950;i:405-9.

29 Hurst AF. Ulcerative colitis. Guy's Hospital Report 1921;71:26-41.

30 Orskov I, Orskov F. Episome-carried surface antigen K88 of Escherichia coli. J Bacteriol 1966;91:69-75.

31 Evans DG, Silver RP, Evans DJ Jr, Chase DG, Gorbach SL. Plasmid-controlled colonisation factor associated with inci- 
dence in Escherichia coli enterotoxigenic for humans. Infect Immun 1975;12:656-67.

32 Williams PH, Sedgwick MI, Evans N, Turner DJ, George RH, McNeish AS. Adherence of an enteropathogenic strain of Escherichia coli to human intestinal mucosa is mediated by a colicinogenic conjugative plasmid. Infect Immun 1978;22:393-402.

33 Sansonetti PJ, Hale TL, Dammin GJ, Kapfer C, Collins HH Jr, Formal SB. Alterations in the pathogenicity of Escherichia coli K12 after transfer of plasmid and chromosomal genes from Shigella flexneri. Infect Immun 1983;39:1392-402.

34 Scheffer J, Konig W, Hacker J, Goebel W. Bacterial adherence and hemolysin production from Escherichia coli induces histamine and leukotriene release from various cells. Infect Immun 1985;50:271-8.

35 Morgan RL, Isaacson RE, Moon HW, Brinton CC, To CC. Immunisation of suckling pigs against enterotoxigenic Escherichia coli-induced diarrhoeal disease by vaccinating dams with purified 987 or K99 pili: protection correlates with pilus homology of vaccine and challenge. Infect Immun 1978;22:771-7.

36 Jayappa HG, Goodnow RA, Geary SJ. Role of Escherichia coli Type I pilus in colonisation of porcine ileum and its protective nature as a vaccine antigen in controlling colibacillosis. Infect Immun 1985;482:350-4.

37 Sherman DM, Acres SD, Sadowski PL, et al. Protection of calves against fatal enteric colibaccilosis by orally administered Escherichia coli K99-specific monoclonal antibody. Infect Immun 1983;42:653-8.

38 Wadstrom T, Faris A, Undahl M, Hjerten S, Agerup B. A new principle for prevention of diarrhoea caused by enterotoxigenic Escherichia coli (ETEC) possessing colonisation factor antigen (CFA/1). Scand J Infect Dis 1981;13:129-32.

Requests for reprints to: Dr DA Burke, Gastroenterology Unit, The General Infirmary, Leeds LS1 3EX, England. 